\title{
Association Between Radiographic Features and Cell Proliferation in Keratocystic Odontogenic Tumor
}

\author{
Asociación entre las Características Radiográficas y la \\ Proliferación Celular en el Tumor Odontogénico Queratoquístico
}

\begin{abstract}
Caroline Brandi Schlaepfer-Sales ${ }^{*}$ Ludmila De Faro Valverde”; Rosane Borges Dias ; Bruna Natália Alves Da Silva Pimentel ${ }^{* *}$; Leonardo De Araújo Melo"; Jean Nunes Dos Santos ${ }^{* *}$; Viviane Almeida Sarmento ${ }^{* * *}$ \& Clarissa Araújo Gurgel Rocha,
\end{abstract}

SCHLAEPFER-SALES, C. B.; VALVERDE, L. F.; DIAS, R. B.; PIMENTEL, B. N. A. S.; MELO, L. A.; DOS SANTOS, J. N.; SARMENTO, V. A. \& ROCHA, C. A. G. Association between radiographic features and cell proliferation in keratocystic odontogenic tumor. Int. J. Odontostomat., 9(2):219-226, 2015.

\begin{abstract}
The radiographic features of an intraosseous lesion are usually associated with the biological behavior of the tumor. In view of the fact that the growth and behavior of keratocystic odontogenic tumors (KCOT) is mainly associated with the proliferation of the cystic epithelium, the objective of the present study was to evaluate the relationship between cell proliferation markers and radiographic features of this tumor. Thirty-seven radiographs of KCOT obtained from 30 patients were scanned and evaluated on a monitor. Sections were submitted to immunohistochemistry for Ki-67, p63, and p53 proteins on an EnVision ${ }^{\mathrm{TM}}$ system. Thirty-one KCOTs were observed in the posterior of the mandible, and the unilocular aspect was predominant $(n=26)$. Nineteen KCOTs distorted the mandibular canal and 11 displaced teeth. Satellite cysts were associated with a multilocular aspect $(P=0.016)$. p53 was in KCOTS with diffuse margins $(p=0.049)$, $p 63$ with NBCCS $(p=0.049)$ KOT and higher KI-67 positive cells was observed in KCOTs presenting distortion of the mandibular canal $(p=0.042)$. The distribution of Ki-67, p63, and p53 positive cells was similar between KCOTs with uni- and multilocular aspects. The results of the present study suggest that cell proliferation in KCOT contributes to the radiographic features of this tumor.
\end{abstract}

KEY WORDS: cell proliferation, odontogenic cysts, radiography.

\section{INTRODUCTION}

Keratocystic odontogenic tumors (KCOTs) originate from remnants of the dental lamina and affect young adults in particular. Although benign, these tumors exhibit aggressive behavior characterized by infiltrative growth, local bone destruction and high rates of recurrence. In general, KCOTs are intraosseous, single or multicystic, and mainly affect the posterior mandible (Gurgel et al., 2008; Pazdera et al., 2012; Andric et al., 2013). Radiographically, KCOTs appear as well-demarcated, unilocular or multilocular radiolucencies (Andric et al.). The tumor occurs in single form or as multiple lesions; in the latter case, KCOTs are frequently associated with Nevoid Basal Cell Carcinoma Syndrome (NBCCS) (Cohen, 1999).

The proliferative activity of the epithelium has been indicated as a probable mechanism responsible for the expansion, local aggressiveness and, possibly, recurrence of KCOTs (Levanat et al., 1996). The overexpression of proteins involved in cell proliferation and the cell cycle such as Ki-67 (Kim et al., 2003; Gurgel et al.; Ba et al., 2010; Ayoub et al., 2011), p53 (Lo Muzio et al., 1999; Gurgel et al.) and p63 (Gurgel et al.) demonstrate the high proliferative potential of the neoplastic epithelium, especially in the suprabasal compartments of the tumor parenchyma.

$\mathrm{Ki}-67$ is a non-histone protein that is expressed throughout the cell cycle, reaching its peak during mitosis, but is not expressed in G0 (Li et al., 1995). Ki-67 has been indicated as a good marker of cell proliferation (Gurgel et al.), more reliable than determining the number of mitotic figures or proliferating cell nuclear antigen (PCNA)-positive cells (Kim et al.).

\footnotetext{
Laboratory of Pathology and Molecular Biology, Oswaldo Cruz Foundation, Salvador, Brazil.

* Laboratory of Oral Surgical Pathology, School of Dentistry, Federal University of Bahia, Salvador, Brazil.

*** Department of Oral Radiology, School of Dentistry, Federal University of Bahia, Salvador, Brazil.
} 
SCHLAEPFER-SALES, C. B.; VALVERDE, L. F.; DIAS, R. B.; PIMENTEL, B. N. A. S.; MELO, L. A.; DOS SANTOS, J. N.; SARMENTO, V. A. \& ROCHA, C. A. G. Association between radiographic features and cell proliferation in keratocystic odontogenic tumor. Int. J. Odontostomat., 9(2):219-226, 2015.

The p53 gene, known as the guardian of the genome, encodes protein p53, which induces cell cycle arrest to allow DNA repair (Gurgel et al.; Andric et al.; Mendes et al., 2011). The loss of function of this protein can lead to accumulation of a series of cellular DNA damage, resulting in a proliferative advantage and escape from the G1 checkpoint, genomic instability, and acquisition of other oncogenic mutations (Mendes et al.).

Protein p63 plays an important role in proliferative activity during the development of craniofacial tissues (Lo Muzio et al., 2005; Gonçalves et al., 2012). In adult tissues, this protein is expressed in the basal layer of the stratified epithelium where it serves as an inhibitor of cell differentiation, thus playing an important role in the maintenance of the proliferative potential and stem cell profile of epithelial precursors (Nekulova et al., 2011).

The radiographic features of an intraosseous lesion are usually associated with the biological behavior of the tumor (Stoelinga, 2001; Chirapathomsakul et al., 2006). Tumors with multilocular features have a greater tendency to recur (Chirapathomsakul et al.). The growth and behavior of KCOTs are mainly associated with the proliferation of the cystic epithelium (Li et al.; Lo Muzio et al., 1999), therefore the objective of the present study was to evaluate the relationship between cell proliferation markers and the radiographic features of this tumor.

\section{MATERIAL AND METHOD}

Sample. The study protocol was approved by the Oswaldo Cruz Foundation Ethics Committee, which is in accordance with the Helsinki Declaration of 1975. The sample consisted of 37 KCOT specimens obtained from 30 patients. In this study, 8 patients presented more than one KCOT, and 5 were diagnosed with NBCCS. All specimens were obtained from excisional biopsies performed for treatment of the tumors. Data regarding clinical history were obtained from the patient records and by interview and are shown in Table I. Morphological analysis was carried out by an experienced pathologist according to the criteria established by the World Health Organization (Barnes et al., 2005) for the diagnosis of KCOT.

Radiographic analysis. Initial diagnostic and postoperative control (at intervals of 6 months) panoramic radiographs were obtained using the same X-ray apparatus (Rotograph Plus, Villa Sistemi Medicali, Milan, Italy). The energy parameters (kilovolts and exposure time) of the apparatus were adjusted according to the age and weight of the patient, ranging from 60 to $90 \mathrm{kV}$ and from 14 to $17 \mathrm{~s}$, respectively. The milliamperage $(10 \mathrm{~mA})$ of the equipment could not be adjusted. Radiographic films (T-MAT G, $12.7 ¥ 30.5 \mathrm{~cm}$ ) in conjunction with intensifying screens (Lanex Regular) were used (both from Kodak Company, New York, USA) and stored in a chassis specific to the X-ray

Table I. Clinical characteristics of patients with Keratocystic odontogenic tumors.

\begin{tabular}{|c|c|c|c|}
\hline \multicolumn{2}{|c|}{ Clinical and Histopathology parameters } & \multirow{2}{*}{$\begin{array}{c}\text { Total }(\mathbf{n}) \\
14\end{array}$} & \multirow{2}{*}{$\begin{array}{r}\% \\
46\end{array}$} \\
\hline Sex & Female & & \\
\hline & Male & 16 & 54 \\
\hline \multirow{5}{*}{ Age (years) } & 10 to 20 & 10 & 34 \\
\hline & 21 to 30 & 7 & 23 \\
\hline & 31 to 40 & 4 & 13 \\
\hline & 41 to 50 & 6 & 20 \\
\hline & $>50$ & 3 & 10 \\
\hline \multirow[t]{2}{*}{ NBCCS } & Yes & 5 & 17 \\
\hline & Sporadic & 25 & 83 \\
\hline \multirow[t]{2}{*}{ Recurrence } & Yes & 14 & 47 \\
\hline & Primary & 16 & 53 \\
\hline \multirow[t]{2}{*}{ Only one KCOT } & NBCCS & 0 & 0 \\
\hline & Not associated with NBCCS & 22 & 100 \\
\hline \multirow[t]{2}{*}{ More than one KCOT } & NBCCS & 5 & 62 \\
\hline & Not associated with NBCCS & 3 & 38 \\
\hline \multirow[t]{2}{*}{ Satellite Cyst Presence } & Yes & 27 & 73 \\
\hline & No & 10 & 27 \\
\hline
\end{tabular}

NBCCS $=$ Nevoid Basal Cell Carcinoma Syndrome; KCOT $=$ Keratocystic odontogenic tumors. 
SCHLAEPFER-SALES, C. B.; VALVERDE, L. F.; DIAS, R. B.; PIMENTEL, B. N. A. S.; MELO, L. A.; DOS SANTOS, J. N.; SARMENTO, V. A. \& ROCHA, C. A. G. Association between radiographic features and cell proliferation in keratocystic odontogenic tumor. Int. J. Odontostomat., 9(2):219-226, 2015.

Table II. Imaging pattern and anatomical location of the Keratocystic odontogenic tumors.

\begin{tabular}{llcc}
\hline & & Total $(\mathbf{n})$ & \% \\
\hline Imaging & Unilocular & 26 & 70.2 \\
& Multilocular & 11 & 29.8 \\
& Diffuse margins & 11 & 29.7 \\
& Well-defined margins & 26 & 70.2 \\
& Distortion of the mandibular canal & 19 & 51.3 \\
& Unrelated with tooth & 10 & 29.7 \\
& Displacement of an adjacent tooth & 11 & 27 \\
Anatomical & Root resorption & 3 & 8.1 \\
location & Posterior mandibular region & 31 & 70.3 \\
& Posterior region of the maxilla & 1 & 2.7 \\
& Anterior region of the maxilla & 0 & 0 \\
& Symphysis/Parasymphysis & 5 & 27 \\
\hline
\end{tabular}

apparatus. The patient was properly protected with a lead vest during radiographic exposure. After exposure, the films were developed in a standardized manner using the temperature-time method in an adequate room using freshly prepared processing solutions (GBX, Kodak Company). Processing was performed in a labyrinth-type dark chamber containing an appropriate safe light (GBX-2 safelight filter, Kodak Company). The radiographs were dried in a hot air oven (EMB, São Paulo, Brazil) and immediately identified using self-adhesive labels.

The images were analyzed by an experienced radiologist, who evaluated the presence or absence of tumor recurrence by comparing the initial and control images. Only KCOTs affecting the same site as the primary tumor were classified as recurrent according to Stoelinga. The imaging pattern and anatomical location of the KCOTs included in the present sample are shown in Table II.

Immunohistochemistry. Sections (4 $\mu$ m thick) were cut from formalin-fixed and paraffin-embedded specimens. The sections were then deparaffinized in xylene and rehydrated in alcohol. Antigen retrieval was performed by wet heat treatment in citrate solution, $\mathrm{pH}$ 6.02 , for $30 \mathrm{~min}$. Endogenous peroxidase was blocked with $3 \%$ hydrogen peroxide for $10 \mathrm{~min}$ in the dark. The sections were then incubated with the following primary antibodies for $1 \mathrm{~h}$ at room temperature: anti-Ki-67 (clone KIS5), anti-p53 (D07), and anti-p63 (clone 4A4) (Dako Corporation, Carpinteria, CA, USA). Next, the EnVision system (Dako Corporation, Carpinteria, CA, USA) was applied for $30 \mathrm{~min}$. The reactions were developed with 3,3-diaminobenzidine (Dako Corporation, Carpinteria, CA, USA) and the sections were counterstained with Harris hematoxylin. Oral squamous cell carcinoma sections were used as positive controls. Sections in which the primary antibody was replaced with normal serum of the same isotype served as negative controls.

For immunohistochemical analysis, 10 consecutive microscopic fields located in a representative area of the tumor were captured. The images were acquired with a light microscope (Axioscop1, Zeiss, Germany) coupled to a digital camera system (Axiocam HRP, Zeiss, Germany, 2004) at $400 ¥$ magnification. The pictures were displayed on an LCD monitor using the Axio-Zeiss operating system, version 4.04 (Zeiss, Germany, 2004). Only cells from the lining epithelium from cases of KCOT that exhibited brown nuclear staining were defined as positive, irrespective of intensity. The localization of Ki-67, p53, and p63 (basal and/or suprabasal) and the number of positive cells were determined using the Image Tool 2.0 program (UTHSCSA, Texas University, Austin, TX, USA). The cases were scored as negative ( $0-5 \%$ positive cells), +1 (6-25\% positive cells), +2 ( $26-50 \%$ positive cells), and +3 ( $>50 \%$ positive cells) as described by Gurgel et al.

Statistical analysis. Statistical analysis was performed using the GraphPad Prism 5.01 program (GraphPad Software, Inc., San Diego, CA, USA). The MannWhitney, Kruskal-Wallis and Fisher exact tests were used for analysis, adopting a level of significance of $5 \%$ and power of the test of $80 \%$.

\section{RESULTS}

Radiographically, 11 (30\%) of the 37 cases of KCOT exhibited diffuse margins. Considering the radiographic appearance of the tumor margin, p53 immunostaining was higher in KCOTs with diffuse margins compared with tumors with well-defined margins ( $p=0.049$; Fig. 1 ). Furthermore, KCOTs with diffuse margins exhibited higher expression of protein p63 in cases associated with NBCCS ( $p=0.049$; Fig. 2) compared with sporadic tumors. On the other hand, higher expression of p63 was observed in sporadic tumors with well-defined margins $(p=0.03$; Fig. 2) compared with tumors associated with NBCCS. 


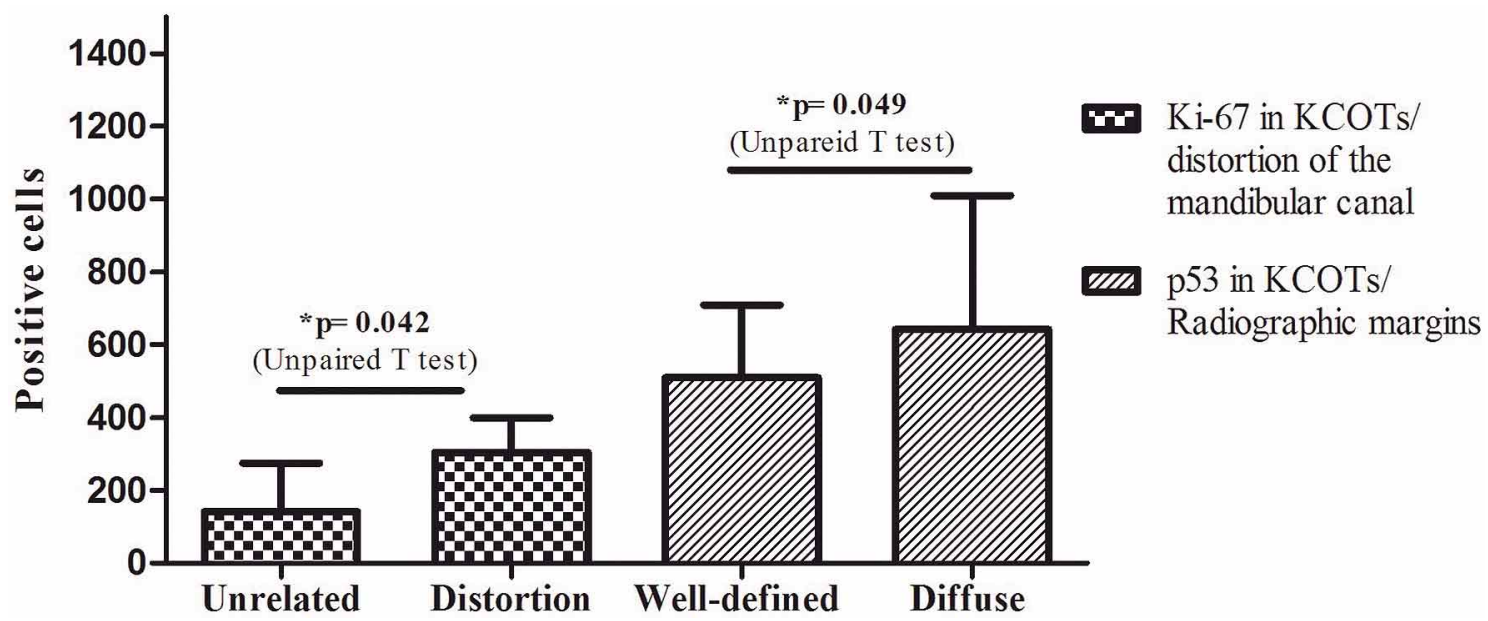

Fig. 1. Ki-67 immunostaining was higher in KCOTs with distortion of the mandibular canal and p53 immunostaining was higher in KCOTs with diffuse margins.

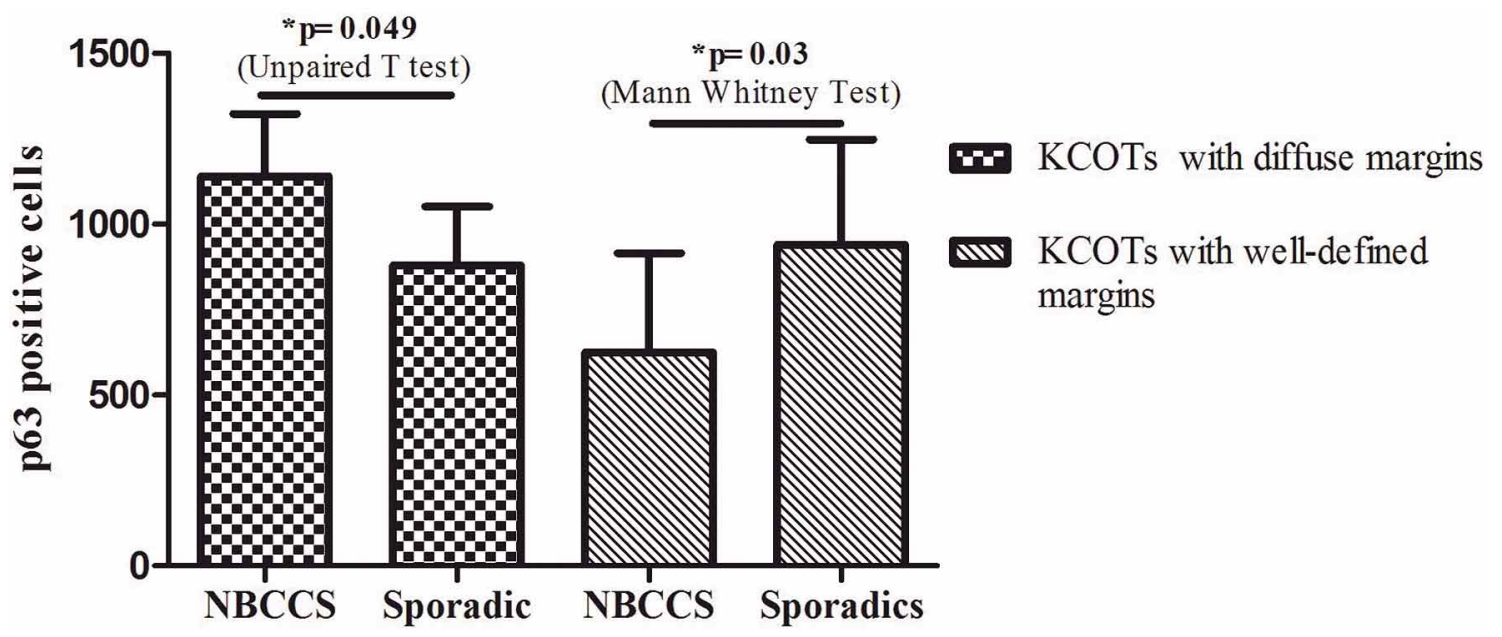

Fig. 2. p63 immunostaining was higher in KCOTs associated with NBCCS with diffuse margins, as well p63 was higher in sporadic KCOTs with well-defined margins.

Among the 31 (83.7\%) tumors affecting the posterior region of the mandible, $19(51.3 \%)$ caused distortion of the mandibular canal. Higher expression of protein Ki-67 was observed in KCOTs causing distortion of the mandibular canal ( $p=0.042$; Fig. 1). Comparing unilocular and multilocular KCOTS, similar expression was observed for Ki-67, p53, and p63 immunostaining (Ki-67, $p=0.053 ; \mathrm{p} 53, \mathrm{p}=0.7$; $\mathrm{p} 63$, $p=1.0)$.

Expression of Ki-67, p53 and p63 was compared between anatomical sites in the posterior mandibular region (body and ramus) and symphysis/ parasymphysis. Analysis showed similar immunostaining of these proteins regarding the anatomical sites (Ki-67, $p=0.4886$; $p 53, p=0.3337$; $\mathrm{p} 63, \mathrm{p}=0.7250$ ).
Among the 14 (37.84\%) recurrent KCOTs, 12 $(85.71 \%)$ were located in the posterior mandibular region. However, the location of the tumor in this region was not associated with recurrence $(p=0.5927)$. Among the $26(70.2 \%)$ tumors exhibiting a unilocular radiotransparency with well-defined margins, 14 $(37.9 \%)$ were located in the periapical region, 19 $(51.3 \%)$ resulted in distortion of the mandibular canal, and $11(29.7 \%)$ caused displacement of an adjacent tooth.

Nuclear immunostaining for Ki-67 was detected in $86.48 \%(n=32)$ of cases, especially in the suprabasal layers. Semi-quantitative analysis revealed a score of +1 in $48.65 \%(n=18)$ of KCOTs, score +2 in $35.13 \%$ $(n=13)$ of cases, and score +3 in only 1 case $(2.72 \%)$. Expression of p53 was observed in most cases ( $n=$ 


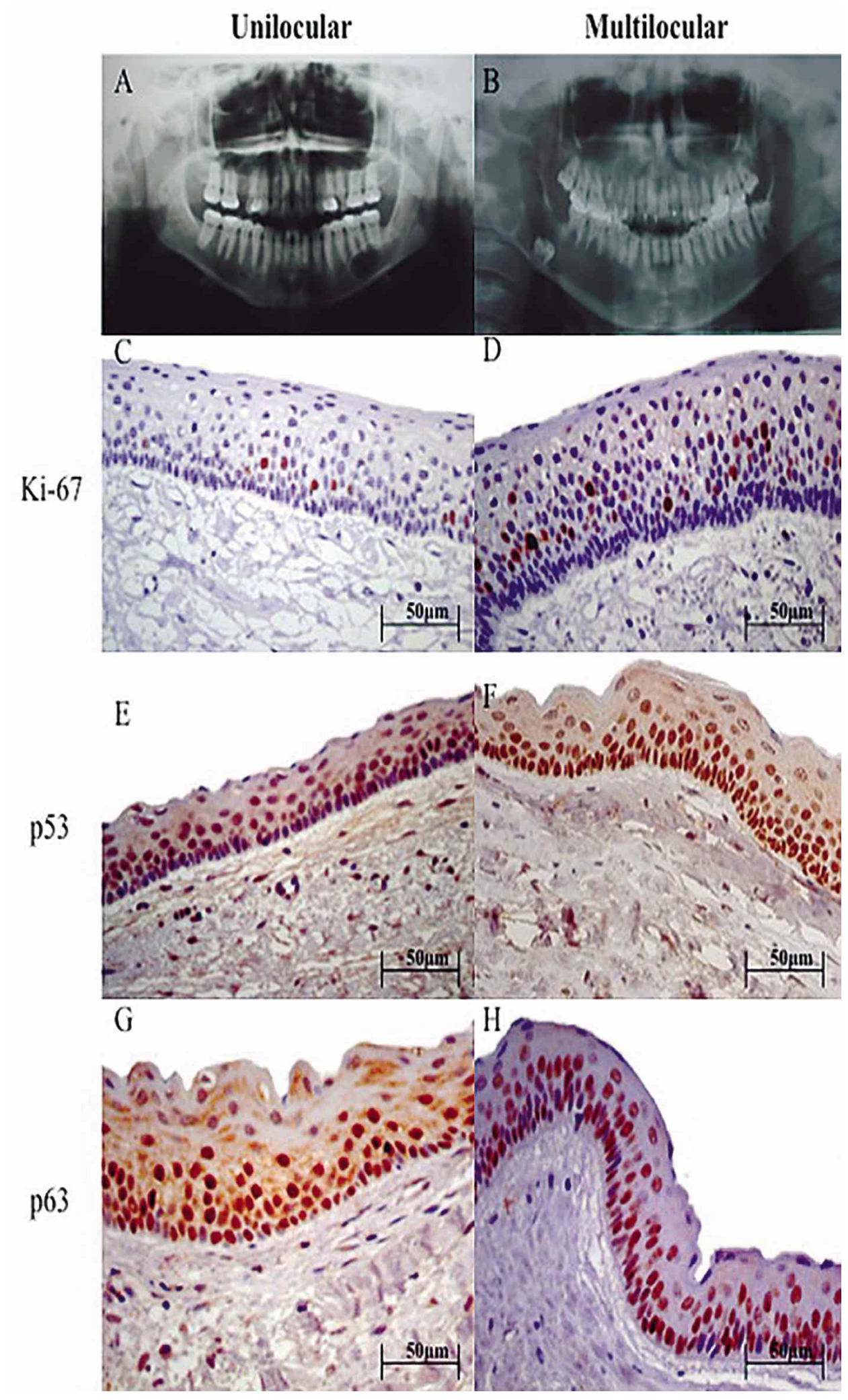

Fig. 3. KCOT immunostaining pattern according to radiographic features: Unilocular radiolucency $(A)$ and multilocular $(B)$. Ki-67 immunostaining (C-D) with score +1 ; p53 immunostaining $(\mathrm{E}-\mathrm{F})$ with score +3 ; p63 immunostaining $(\mathrm{G}-\mathrm{H})$ with score +3 .
$34 ; \quad 91.89 \%)$, with p r e d o m i n a $n$ t immunostaining in the suprabasal layers. Of these, $51.35 \%(n=19)$ scored $+3,29.73 \%(n=11)$ scored +2 , and $10.81 \%$ $(n=4)$ scored +1 . Positive nuclear staining for $p 63$ (score +3$)$ was observed in all cases of KCOT $(n=37$; $100 \%$ ), with distribution in all layers of the epithelium. Figure 3 shows the immunostaining pattern of the proteins studied.

\section{DISCUSSION}

Few studies in the literature have evaluated the association between the proliferative behavior of the epithelium in KCOT and the imaging findings (Kim et al.; Ba et al.) and most studies have compared the proliferative potential of KCOTs with other tumors (Metgud \& Gupta, 2013) or odontogenic cysts ( $\mathrm{Li}$ et al.). In the present sample, an association was observed between the immunoexpression of Ki67, p53, and p63 in the neoplastic epithelium and some radiographic features of KCOT. Immunostaining for p53 protein was higher in KCOTs with diffuse margins. In addition, KCOTs with diffuse margins showed higher expression of $p 63$ protein in cases associated with NBCCS. On the other hand, expression of p63 was higher in sporadic 
tumors with well-defined margins. Furthermore, higher expression of protein Ki-67 was observed in tumors causing distortion of the mandibular canal.

KCOTs are generally asymptomatic (Pazdera et al.; Andric et al.). Some tumors are detected after the occurrence of pathologic fractures because of the tendency of the tumor to extend into the medullary cavity (Shear, 2003). Therefore, imaging examinations are fundamental for the early diagnosis of KCOTs and are essential to define the most adequate treatment for these tumors (Min et al., 2013). Although KCOTs exhibit different radiographic patterns, a unilocular radiolucency with well-defined margins is the most common (Ba et al.). This pattern was observed in most $(n=26 ; 70.2 \%)$ of the 37 tumors studied here.

According to the literature, KCOTs with a multilocular radiographic appearance have a greater tendency to recur than the unilocular variant (Chirapathomsakul et al.). One of the reasons for this is that surgical removal of these tumors is more difficult (Andric et al.). Similarly, distortion of the mandibular canal is an indicator of the aggressiveness of the multilocular type. However, no association between these variables could be established in the present study, probably because of the small number of tumors with a multilocular pattern.

Because deregulation of the cell cycle is probably important for the pathogenesis of KCOT (Andric et al.), studies have evaluated the immunoexpression of proteins related to cell proliferation (Gurgel et al.; Mendes et al.; Gonçalves et al.). Protein $\mathrm{Ki}-67$ staining has been used as a marker of cell proliferation in KCOTs because it is more reliable than determining the number of mitotic figures or PCNA-positive cells (Gurgel et al.; Ayoub et al.; Mendes et al.). In the present study, Ki-67immunostained cells were mainly found in the suprabasal layer, in agreement with Ayoub et al. On the other hand, Ki-67 immunostaining was detected throughout the cystic epithelium in KCOTs of syndromic patients.

Most anti-p53-positive cells were also found in the suprabasal layers of the epithelium, in agreement with the literature ( $\mathrm{Li}$ et al.). According to Slootweg (1995), detection of this protein in KCOTs suggests a disturbance in the regulation of cell proliferation. Note that protein p53 has a short half-life, i.e., under normal conditions it does not reach high concentrations in the cells (Gurgel et al.).
Protein p63 has 2 isoforms, TAp63 and $\Delta$ Np63, with distinct functions. The antibody specific for the human $\Delta \mathrm{Np63}$ isoform was used in the present study, which exerts anti-apoptotic activity and is expressed in cells with apparent proliferative capacity and immature cells. All 37 KCOTs exhibited positive p63 immunostaining $($ score +3$)$ in all layers of the epithelium, which suggests the presence of immature cells in this tumor (Gurgel et al.). Furthermore, Lo Muzio et al. (2005) suggested that p63 immunostaining in odontogenic tumors is an indicator of a poor prognosis.

The present results suggest deregulation of the cell cycle in KCOTs, in agreement with studies indicating the presence of a suprabasal proliferative compartment in these tumors (Gurgel et al.). In this context, despite Shear (2002) demonstrated immunostaining for cytokeratin 10 (CK10), Dos Santos et al. (2009) reported the absence of positive cells for CK10 in KCOTs. This protein is involved in the final differentiation and keratinization of KCOTs, suggesting impaired cell maturation. These results support the hypothesis that KCOTs contain a proliferating suprabasal epithelial compartment.

In conclusion, the results of the present study suggest that cell proliferation in KCOTs is associated to some radiographic features of these tumors. In this study, immunostaining for Ki-67, p53 and p63 was analyzed in 10 representative areas of the tumors. Thus, studies to investigate the full extent of the tumor are needed to clarify the association between the radiographic findings and the proliferative potential of KCOTs.

\section{ACKNOWLEDGMENTS}

The authors would like to thank Lorna O' Brien for providing English translation and consulting services.

SCHLAEPFER-SALES, C. B.; VALVERDE, L. F.; DIAS, R. B.; PIMENTEL, B. N. A. S.; MELO, L. A.; DOS SANTOS, J. N.; SARMENTO, V. A. \& ROCHA, C. A. G. Asociación entre las características radiográficas y la proliferación celular en el tumor odontogénico queratoquístico. Int. J. Odontostomat., 9(2):219-226, 2015.

RESUMEN: Las características radiográficas de una lesión intraósea se asocian generalmente con el comportamiento biológico del tumor. Debido a esto, el crecimiento y comportamiento de los tumores odontogénicos 
queratoquísticos se asocian principalmente con la proliferación del epitelio quístico. El objetivo del estudio fue evaluar la relación entre los marcadores de proliferación celular y las características radiológicas de este tumor. Se escanearon y evaluaron 37 radiografías de tumores odontogénicos queratoquísticos obtenidos de 30 pacientes y las secciones de sus biopsias fueron sometidas a evaluación inmunohistoquímica para las proteíneas Ki-67, p63 y p53 en un sistema Envision ${ }^{\mathrm{TM}}$. Se observaron 31 tumores odontogénicos queratoquísticos en el área posterior de la mandíbula, con predominio del aspecto unilocular $(n=26)$. Diecinueve tumores odontogénicos queratoquísticos distorsionaron el canal mandibular y se observaron 11 dientes desplazados. Los quistes satélites se asociaron con el aspecto multilocular $(P=0,016)$. La distribución de células positivas para Ki-67, p63 y p53 fue similar entre tumores odontogénicos queratoquísticos con aspectos uniformes y multiloculares, y no estaban relacionadod con la distorsión del canal mandibular $(P>0,05)$ o con el desplazamiento del diente $(P>0,05)$. Los resultados del presente estudio sugieren que la proliferación celular en tumores odontogénicos queratoquísticos contribuye a las características radiográficas de este tumor.

PALABRAS CLAVE: proliferación celular, quistes odontogénicos, radiografía.

\section{REFERENCES}

Andric, M.; Brkovic, B.; Jurisic, V.; Jurisic, M. \& Milasin, J. Keratocystic Odontogenic Tumors - Clinical and Molecular Features. In: Motamedi, M. H. K. (Ed.). A Textbook of Advanced Oral and Maxillofacial Surgery. Rijeka, InTech, 2013. Available at: http:// www.intechopen.com/books/a-textbook-of-advancedoral-and-maxillofacial-surgery/keratocystic-odontogenictumors-clinical-and-molecular-features

Ayoub, M. S.; Baghdadi, H. M. \& El-Kholy, M. Immunohistochemical detection of laminin-1 and Ki-67 in radicular cysts and keratocystic odontogenic tumors. B. M. C. Clin. Pathol., 11:4, 2011.

Ba, K.; Li, X.; Wang, H.; Liu, Y.; Zheng, G.; Yang, Z.; Li, M.; Shimizutani, K. \& Koseki, T. Correlation between imaging features and epithelial cell proliferation in keratocystic odontogenic tumour. Dentomaxillofac. Radiol., 39(6):36874, 2010.

Barnes, L.; Eveson, J. W.; Reichart, P. \& Sindransky, D. World Health Organization Classification of Tumours: Pathology and Genetics of Head and Neck Tumours. Lyon, IARC Press, 2005.

Chirapathomsakul, D.; Sastravaha, P. \& Jansisyanont, P. A. A review of odontogenic keratocysts and the behavior of recurrences. Oral Surg. Oral Med. Oral Pathol. Oral Radiol. Endond., 101(1):5-9, 2006.

Cohen, M. M. Jr. Nevoid basal cell carcinoma syndrome: molecular biology and new hypotheses. Int. J. Oral Maxillofac. Surg., 28(3):216-23, 1999.

Dos Santos, J. N.; Oliveira, G. Q.; Gurgel, C. A.; de Souza, R. O.; Sales, C. B.; de Aguiar Pires Valença Neto, A. \& Ramos, E. A. Altered expression of cytokeratins in primary, recurrent and syndrome keratocystic odontogenic tumors. J. Mol. Histol., 40(2):269-75, 2009.

Gonçalves, C. K.; Fregnani, E. R.; Leon, J. E.; Silva-Sousa, Y. T. \& Perez, D. E. Immunohistochemical expression of p63, epidermal growth factor receptor (EGFR) and notch1 in radicular cysts, dentigerous cysts and keratocystic odontogenic tumors. Braz. Dent. J., 23(4):337-43, 2012.

Gurgel, C. A.; Ramos, E. A.; Azevedo, R. A.; Sarmento, V. A.; da Silva Carvalho, A. M. \& dos Santos, J. N. Expression of $\mathrm{Ki}-67, \mathrm{p} 53$ and p63 proteins in keratocyst odontogenic tumours: an immunohistochemical study. J. Mol. Histol., 39(3):311-6, 2008.

Kim, D. K.; Ahn, S. G.; Kim, J. \& Yoon, J. H. Comparative Ki67 expression and apoptosis in the odontogenic keratocyst associated with or without an impacted tooth in addition to unilocular and multilocular varieties. Yonsei Med. J., 44(5):841-6, 2003.

Levanat, S.; Gorlin, R. J.; Fallet, S.; Johnson, D. R.; Fantasia, J. E. \& Bale, A. E. A two-hit model for developmental defects in Gorlin syndrome. Nat. Genet., 12(1):85-7, 1996.

Li, T. J.; Browne, R. M. \& Matthews, J. B. Epithelial cell proliferation in odontogenic keratocysts: a comparative immunocytochemical study of Ki67 in simple, recurrent and basal cell naevus syndrome (BCNS)-associated lesions. J. Oral Pathol. Med., 24(5):221-6, 1995.

Lo Muzio, L.; Staibano, S.; Pannone, G.; Bucci, P.; Nocini, P. F.; Bucci, E. \& De Rosa, G. Expression of cell cycle and apoptosis-related proteins in sporadic odontogenic keratocysts and odontogenic keratocysts associated with the nevoid basal cell carcinoma syndrome. J. Dent. Res., 78(7):1345-53, 1999.

Lo Muzio, L.; Santarelli, A.; Caltabiano, R.; Rubini, C.; Pieramici, T.; Fior, A.; Trevisiol, L.; Carinci, F.; Leonardi, R.; Bufo, P.; Lanzafame, S. \& Piatelli, A. p63 expression in odontogenic cysts. Int. J. Oral Maxillofac. Surg., 34(6):668-73, 2005.

Mendes, R. A.; Carvalho, J. F. \& van der Waal, I. A comparative immunohistochemical analysis of COX-2, p53, and Ki-67 expression in keratocystic odontogenic tumors. Oral Surg. Oral Med. Oral Pathol. Oral Radiol. Endod., 111(3):333-9, 2011. 
SCHLAEPFER-SALES, C. B.; VALVERDE, L. F.; DIAS, R. B.; PIMENTEL, B. N. A. D.; MELO, L. D.; Dos SANTOS, J. N.; SARMENTO, V. A. \& ROCHA, C. A. G. Association between radiographic features and cell proliferation in keratocystic odontogenic tumor. Int. J. Odontostomat., 9(2):219-226, 2015.

Metgud, R. \& Gupta, K. Expression of cell cycle and apoptosis-related proteins in ameloblastoma and keratocystic odontogenic tumor. Ann. Diagn. Pathol., 17(6):518-21, 2013.

Min, J. H.; Huh, K. H.; Heo, M. S.; Choi, S. C.; Yi, W. J.; Lee, S. S.; Bae, K. H. \& Choi, J. W. The relationship between radiological features and clinical manifestation and dental expenses of keratocystic odontogenic tumor. Imaging Sci. Dent., 43(2):91-8, 2013.

Nekulova, M.; Holcakova, J.; Coates, P. \& Vojtesek, B. The role of p63 in cancer, stem cells and cancer stem cells. Cell. Mol. Biol. Lett., 16(2):296-327, 2011.

Pazdera, J.; Kolar, Z.; Zboril, V.; Tvrdy, P. \& Pink, R. Odontogenic keratocysts/keratocystic odontogenic tumours: biological characteristics, clinical manifestation and treatment. Biomed. Pap. Med. Fac. Univ. Palacky Olomouc Czech Repub., 158(2):170-4, 2012.

Shear, M. The aggressive nature of the odontogenic keratocyst: is it a benign cystic neoplasm? Part 3. Immunocytochemistry of cytokeratin and other epithelial cell markers. Oral Oncol., 38(5):407-15, 2002.

Shear, M. Odontogenic keratocysts: natural history and immunohistochemistry. Oral Maxillofac. Surg. Clin. North Am., 15(3):362-77, 2003.

Stoelinga, P. J. Long-term follow-up on keratocysts treated according to a defined protocol. Int. J. Oral Maxillofac. Surg., 30(1):14-25, 2001.

Slootweg, P. J. p53 protein and Ki-67 reactivity in epithelial odontogenic lesions. An immunohistochemical study. J. Oral Pathol. Med., 24(9):393-7, 1995.
Correspondence to:

Clarissa Araújo Gurgel Rocha

Federal University of Bahia

Av. Araújo Pinho, 62, 40110-150,

Salvador Bahia

BRAZIL

Tel.: +55 (71) 32839019

Email: gurgel.clarissa@gmail.com

Received: 08-04-2015

Accepted: 02-07-2015 